\title{
PENGARUH MODEL BELAJAR PROJECT BASED LEARNING (PJBL) TERHADAP HASIL BELAJAR SISWA PADA MATA PELAJARAN INSTALASI TENAGA LISTRIK SISWA XI DI SMK NEGERI 1 PERCUT SEI TUAN TA.2019/2020
}

\author{
Arif Sahron ${ }^{1}$, Baharuddin $^{2}$ \\ 1,2Pendidikan Teknik Elektro, Fakultas Teknik Universitas Negeri Medan \\ 1.
}

\begin{abstract}
This study aims to determine the effect of the project based learning (PJBL) learning model on the learning outcomes of electric power installation in class XI TITL at SMK. This study used a quasiexperimental method with a Posttest Only Control Group Design model. The number of research subjects was 62 students, consisting of 32 students of class XI TITL 1 as the experimental class and 32 students of class XI TITL 2 as the control class. The data collection technique used was a multiple choice written test which had been tested for validity, reliability, difficulty level, and differentiation power. The results showed that the learning outcomes of the project based learning model showed that the students' average score in the experimental class was 77.33 while the control class was 71.16. From the results of the calculation of the hypothesis test, it is obtained $t_{\text {count }} 3.261$ and $t_{\text {table }}$ is 1.670 , then $t_{\text {count }}>t_{\text {table }}$ or $3.261>1.670$, so it can be concluded that the alternative hypothesis $(\mathrm{Ha})$ in this study is accepted while rejecting the null hypothesis $(\mathrm{Ho})$ in other words the learning outcomes of class XI students. Electrical Power Installation Techniques on the competence of understanding the installation and measurement of earth systems with a project based learning (PPA) learning model are higher than student learning outcomes using conventional learning models.
\end{abstract}

\section{Key Words: Project based learning model, learning outcomes}

\begin{abstract}
Abstrak
Penelitian ini bertujuan untuk mengetahui pengaruh model pembelajaran project based learning (PJBL) terhadap hasil belajar instalasi tenaga listrik kelas XI TITL di SMK. Penelitian ini menggunakan metode quasi eksperimen dengan model Posttes Only Control Group Design. Jumlah subjek penelitian 62 orang peserta didik, yang terdiri dari 32 peserta didik kelas XI TITL 1 sebagai kelas eksperimen dan 32 peserta didik kelas XI TITL 2 sebagai kelas kontrol. Teknik pengumpulan data yang digunakan adalah tes tertulis berbentuk pilihan ganda yang telah terlebih dahulu diuji Validitas,reliabilitas,tingkat kesukaran, dan daya beda. Hasil penelitian diketahui bahwa hasil belajar model belajar project based learning diperoleh nilai rata-rata siswa pada kelas eksperimen yaitu 77,33 sedangkan kelas kontrol 71,16. Dari hasil perhitungan uji hipotesis diperoleh $t_{\text {hitung }} 3,261$ dan $t_{\text {tabel }}$ adalah 1,670, maka $t_{\text {hitung }}>t_{\text {tabel }}$ atau 3,261 >1,670, sehingga dapat disimpulkan bahwa hipotesis alternative (Ha) dalam penelitian ini diterima sekaligus menolak hipotesis nihil (Ho) dengan kata lain hasil belajar siswa kelas XI Teknik Instalasi Tenaga Listrik pada kompetensi memahami instalasi dan pengukuran sistem pembumian dengan model belajar project based learning (PJBL) lebih tinggi dari hasil belajar siswa dengan menggunakan model belajar konvensional.
\end{abstract}

Kata Kunci: Model belajar project based learning, hasil belajar

\section{PENDAHULUAN}

Dalam rangka mencapai tujuan pendidikan pemerintah khususnya depdiknas telah banyak melakukan berbagai upaya dan kebijakan seperti mengadakan perbaikan kurikulum, perubahan kurikulum tingkat satuan pendidikan yang penyusunan kurikulumnya dilakukan oleh pemerintah menjadi K13 yaitu kurikulum yang memiliki empat aspek, yaitu aspek pengetahuan, aspek keterampilan, aspek sikap, dan aspek prilaku. Di dalam kurikulum 2013, terutama di materi pembelajaran terdapat materi yang ditambahkan. Namun, indicator ke arah mutu pendidikan belum menunjukkan peningkatan yang signifikan. Hal yang memperihatinkan dapat dilihat adalah hasil belajar siswa yang belum mencapai harapan.

Salah satu lembaga pendidikan formal tersebut adalah SMK N 1 Percut Sei Tuan, yang 
memiliki bidang teknik instalasi tenaga listrik (ITL). Sekolah menengah kejuruan Negeri 1 Percut Sei Tuan adalah salah satu bidang keteknikan dimana para lulusannya diharapkan mampu bersaing dalam dunia industry. Namun, berdasarkan hasil obervasi yang dilaksanakan pada tanggal 19 November dengan salah satu guru di SMK N 1 Percut Sei Tuan, bahwa nilai yang diperoleh siswa pada mata pelajaran instalasi tenaga listrik (ITL) masih tergolong rendah.

Banyak yang mempengaruhi kualitas pembelajaran, diantaranya adalah model pembelajaran. Salah satu jalan yang dapat ditempuh oleh seorang guru dalam pencapaian peningkatan hasil belajar adalah menyesuaikan model pembelajaran dengan memanfaatkan sarana dan prasarana pendidikan sesuai dengan kondisi sekolah.

Hakikatnya belajar bukan hanya sekedar kemampuan untuk menguasai kompentensikompetensi kejuruan yang ditandai dengan perolehan nilai yang standar, namun harus ada peningkatan hasil belajar yang ditunjukkan dari hasil belajar siswa, sehingga guru tidak hanya sekedar pemenuhan pencapaian standart kelulusan tapi kehendaknya guru juga memotivasi siswa agar terus mendapatkan peningkatan hasil belajar yang lebih baik.

Perlu dilakukan perbaikan atau pembaharuan dari proses belajar mengajar untuk mencapai tujuan yang diharapkan dengan hasil belajar yang lebih baik. Pembaharuan yang dimaksud bisa dilakukan dari beberapa hal, salah satu diantaranya adalah pembaharuan terhadap model pembelajaran. Seorang guru harus menggunakan model pembelajaran dengan pertimbangan yang matang sesuai dengan kebutuhan siswa yang juga mampu menciptakan suasana yang menyenangkan bagi siswa. Untuk mengadaptasikan pembelajaran dengan individual siswa dan memungkinkan keterlibatan siswa untuk bekerja sama dengan siswa lainnya yang berbeda secara akademik sehingga tercipta sikap positif diantara mereka. Kondisi ini akan mempengaruhi hasil belajar siswa secara individu.

Terdapat banyak alternative model pembelajaran yang dapat diterapkan pada proses belajar mengajar dalam ruang kelas. Salah satunya dengan model pembelajaran yang dirasa efektif adalah model pembelajaran project based learning. Langkah-langkah dalam pembelajaran berbasis proyek (PjBL) akan menempatkan mahasiswa sebagai peserta didik yang aktif dalam menggali, mengeksplorasi, maupun menyampaikan ide-ide yang mereka miliki untuk menyelesaikan proyek yang diberikan oleh guru. Metode ini juga memberikan kesempatan kepada guru untuk mengelola pembelajaran di kelas dengan melibatkan kerja proyek yang memuat tugas-tugas yang kompleks berdasarkan per-masalahan (problem) yang diberikan kepada siswa untuk meningkatkan kemampuan berpikir kritis, kreatif, dan kolaboratif. Langkah dalam pembelajaran berbasis proyek yang bertujuan mengumpulkan dan mengintegrasi-kan pengetahuan baru berdasarkan pengalam-annya dalam beraktivitas secara nyata, dan menuntut mahasiswa untuk melakukan kegiatan merancang, melakukan kegiatan investi-gasi atau penyelidikan, memecahkan masalah, membuat keputusan, serta memberikan ke-sempatan kepada siswa untuk bekerja secara mandiri maupun kelompok. Dengan proses belajar yang demikian, diharapkan siswa dapat meningkatkan hasil belajar .

Siswa kelas XI instalasi tenaga listrik (ITL) pada mata pelajaran instalasi tenaga listrik masih rendah hasil belajar siswa SMK N 1 Percut Sei Tuan. Rendahnya hasil belajar siswa dipengaruhi oleh banyak faktor, diantaranya faktor dari individu dan faktor dari luar individu. Masalah lain yang diduga menjadi penyebab rendahnya hasil belajar siswa dalam proses pembelajaran mata pelajaran instalasi tenaga listrik kemungkinan proses pembelajaran masih menggunakan model pembelajaran konvensional.

Sesuai dengan latar belakang masalah di atas, maka penelitian ini dibatasi pada pengaruh model belajar project based learning terhadap hasil belajar siswa pada mata pelajaran intalasi tenaga listrik kompetensi dasar pengetahuan 3.7 memahami instalasi dan pengukuran sistem pembumian di kelas XI Teknik Instalasi Tenaga Listrik SMK Negeri 1 Percut Sei Tuan.

\section{Hasil Belajar}

Hasil belajar merupakan proses dalam diri individu yang berinteraksi dengan lingkungan untuk mendapatkan perubahan dalam perilakunya. Belajar adalah aktivitas mental/psikis yang berlangsung dalam interaksi aktif dengan lingkungan yang menghasilkan perubahan-perubahan dalam pengetahuan, keterampilan dan sikap (Winkel, 1999:53). Perubahan itu diperoleh melalui usaha (bukan karena kematangan), menetap dalam waktu yang relatif lama dan merupakan hasil pengalaman. 
Minat terhadap kajian proses belajar dilandasi oleh keinginan untuk memberikan pelayanan pengajaran dengan hasil yang maksimal. Pengajaran merupakan proses membuat belajar terjadi didalam diri anak. Pengajaran bukanlah menginformasikan materi agar dikuasai oleh mahasiswa, tetapi memberikan kondisi agar mahasiswa mengusahakan terjadi belajar dalam dirinya. Pengajaran harus didasarkan atas pemahaman tentang bagaimana anak belajar.

Proses belajar dapat melibatkan aspek kognitif, afektif, dan psikomotorik. Pada belajar kognitif, prosesnya mengakibatkan perubahan dalam aspek kemampuan berpikir (cognitive), pada belajar afektif mengakibatkan perubahan dalam aspek kemampuan merasakan (afective), sedangkan belajar psikomotorik memberikan hasil belajar berupa keterampilan (psychomotoric).

Berdasarkan teori belajar di atas dapat disimpulkan bahwa belajar adalah proses untuk membuat perubahan dalam diri mahasiswa dengan cara berinteraksi dengan lingkungan untuk mendapatkan perubahan dalam aspek kognitif, afektif, psikomotorik. Pada teori belajar perilaku, proses belajar cukup dilakukan dengan mengikatkan antara stimulus dan respons secara berulang, sedangkan pada teori kognitif, proses belajar membutuhkan pengertian dan pemahaman.

Belajar dilakukan untuk mengusahakn adanya perubahan perilaku pada individu yang belajar. Perubahan perilaku iru merupakan perolehan yang menjadi hasil belajar. Hasil belajar adalah perubahan yang mengakibtkan manusia berubah dalam sikap dan tingkah lakunya (Winkel, 1996:51). Aspek perubahan itu mengacu kepada taksonomi tujuan pengajaran yang dikembangkan oleh Bloom, Simpson, dan Harrow mencakup aspek kognitif, afektif, dan psikomotorik (Winkel,1996:244).

\section{Model Pembelajaran}

Dari kerangka teoretis yang lebih umum, model pembelajaran, menurut Isjoni (2012: 147), merupakan model yang digunakan guru untuk meningkatkan motivasi belajar, sikap belajar di kalangan siswa, mampu berpikir kritis, memiliki keterampilan sosial, dan pencapaian hasil pembelajaran yang lebih. Model pembelajaran berisi model-model pilihan guru untuk tujuan-tujuan tertentu di kelas. Sementara, model, menurut Kemp (dalam Rusman, 2014: 132), merupakan suatu kegiatan pembelajaran yang harus dikerjakan oleh guru dan siswa agar tujuan pembelajaran tercapai secara efektif dan efisien. Sementara itu, Dick dan carey menyatakan model pembelajaran sebagai suatu perangkat materi dan prosedur pembelajaran yang digunakan secara bersama-sama untuk menimbulkan hasil belajar pada siswa. Satu model pembelajaran dapat menggunakan beberapa metode. Model pembelajaran juga dilandasi oleh berbagai prinsip dan teori pengetahuan, diantaranya prinsipprinsip pembelajaran, teori psikologis, sosiologis, analisis sistem, atau teori lain yang membantu (dalam Rusman, 2014:132). Sehubungan dengan itu, model pembelajaran merupakan seperangkat materi dan prosedur pembelajaran atas dasar landasan teoretis tertentu untuk tujuan pembelajaran tertentu.

Pendapat yang lebih komprehensif diungkapkan oleh Miftahul Huda. Model pembelajaran didefinisikan sebagai gambaran keseluruhan pembelajaran yang kompleks dengan berbagai teknik dan prosedur yang menjadi bagian pentingnya. Di dalam kompleksitas model pembelajaran, terdapat metode, teknik, dan prosedur yang saling bersinggungan satu dengan lainnya (Miftahul Huda, 2014). Sehingga model pembelajaran adalah satu perangkat pembelajaran yang kompleks yang menaungi metode, teknik, dan prosedur.

Berdasarkan pengertian-pengertian model pembelajaran di atas, setiap model pembelajaran memiliki ciri-ciri, sebagai berikut. 1) Berdasarkan teori pendidikan dan teori belajar dari para ahli tertentu. 2) Mempunyai misi atau tujuan pendidikan tertentu. 3) Dapat dijadikan pedoman perbaikan kegiatan belajar mengajar di kelas. 4) Memiliki bagian-bagian model yang dinamakan: (a) urutan langkah-langkah pembelajaran (syntax), (b) prinsip-prinsip reaksi, (c) sistem sosial, dan (d) sistem pendukung. 5) Memiliki dampak sebagai akibat 
terapan model pembelajaran, meliputi: dampak pembelajaran berupa hasil belajar yang terukur dan dampak pengiring berupa hasil belajar jangka panjang. 6) Adanya desain instruksional atau persiapan mengajar dengan berpedoman pada model pembelajaran yang dipilih.

\section{Pembelajaran Project based Learning (PJBL)}

Pembelajaran berbasis proyek adalah suatu model pembelajaran yang melibatkan suatu proyek dalam proses pembelajaran. Proyek yag dikerjakan oleh peserta didik dapat berupa proyek perseorangan atau kelompok dan dilaksanakan dalam jangka waktu tertentu secara kolaboratif, menghasilkan sebuah produk, yang hasilnya kemudian akan ditampilkan atau dipresentasikan. Pelaksanan proyek dilakukan secara kolaboratif, inovatif, unik, dan yang berfokus pada pemecahan masalah yang berhubungan dengan kehidupan peserta didik. Model ini sebagai ganti penggunaan suatu model pembelajaran yang masih bersifat teacher-centered yang cenderung membuat pembelajaran lebih pasif dibandingkan dengan guru. Hal tersebut mengakibatkan motivasi belajar peserta didik menjadi rendah sehingga kinerja kinerja ilmiah mereka menurun.

Pada PBP, peserta didik terlibat aktif dalam memecahkan masalah yang ditugaskan oleh guru dalam bentuk proyek. Peserta didik aktif mengelola pembelajaran dengan bekerja secara nyata yang menghasilkan produk. Jadi, hasil akhir dari proses pembelajaran adalah produk yang bias bermakna dan bermanfaat. PBP dapat mereduksi kompetensi di dalam kelas dan mengarahkan peserta didik lebih kolaboratif dari pada bekerja sendiri-sendiri.

Pembelajaran berbasis proyek dipandang tepat sebagai satu model untuk pendidikan teknologi untuk merespon isu-isu peningkatan kualitas pendidikan teknologi dan perubahanperubahan besar yang terjadi di dunia kerja. Berbeda dengan model-model pembelajaran tradisional pendek, terisolasi/ lepas-lepas, dan aktivitas pembelajaran berpusat pada guru; model pembelajran project based learning menekankan kegiatan belajar yang relative berdurasi panjang, holistic interdisipliner, perpusat pada siswa, dan terintegrasi dengan praktik dan isu-isu dunia nyata.

Pembelajaran berbasis proyek merupakan model pembelajaran yang berfokus pada peserta didik dalam kegiatan pemecahan masalah dan tugas-tugas bermakna lainnya. Pelaksanaan PBP dapat memberi peluang pada peserta didik untuk bekerja mengkonstruksi tugas yang diberikan guru yang puncaknya dapat menghasilkan produk karya peserta didik. Manfaat pembelajaran berbasis proyek (PBP) diantaranya adalah sebagai berikut :

a) Memperoleh pengetahuan dan keterampilan baru dalam pembelajaran.

b) Meningkatkan kemampuan peserta didik dalam pemecahan masalah.

c) Membuat peserta didik lebih aktif dalam memecahkan masalah yang kompleks dengan hasil produk nyata berupa barang atau jasa.

d) Mengembangkan dan meningkatkan keterampilan peserta didik dalam mengelola sumber/alat/bahan untuk menyelesaikan tugas.

e) Peserta didik membuat keputusan dan membuat kerangka kerja.

f) Peserta didik merancang proses untuk mencapai hasil belajar.

g) Peserta didik melakukan evaluasi secara kontinu.

h) Hasil akhir berupa produk dan dievaluasi kualitasnya.

kegiatan yang harus dilakukan pada setiap langkah PBP adalah sebagai berikut :

1) Penentuan proyek

2) Perancangan langkah penyelesaian proyek

3) Penyusunan jadwal pelaksanaan proyek

4) Penyelesaian proyek dengan fasilitas dan monitoring guru

5) Penyusunan laporan dan presentasi hasil proyek

6) Evaluasin proses dan hasil proyek 
Kelebihan dari pembelajaran berbasis proyek antara lain :

1) Meningkatkan motivasi

2) Meningkatkan kemampuan pemecahan masalah

3) Meningkatkan kolaborasi

4) Meningkatkan keterampilan mengelola sumber

5) Mendorong peserta didik untuk mengembankan dan keterampilan komunikasi

6) Membuat suasana belajar menjadi menyenangkan

Kelemahan pembelajaran berbasis proyek adalah sebagai berikut :

1) Membutuhkan banyak waktu untuk menyelesaikan masalah.

2) Membutuhkan biaya yang cukup.

3) Membutuhkan guru yang terampil.

4) Membutuhkan fasilitas, peralatan dan bahan memadai.

5) Kesulitan melibatkan semua peserta didik dalam kerja kelompok.

\section{METODE}

Lokasi penelitian ini dilaksanakan di kelas XI Program Keahlian Teknik Instalasi Tenaga Listrik SMKN 1 Percut Sei Tuan. Waktu penelitian dilaksanakan pada semester genap tahun ajaran 2019/2020. Populasi dalam penelitian ini adalah siswa kelas XI Teknik Instalasi Listrik SMK N 1 Percut sei Tuan tahun pembelajaran 2019/2020. Pengambilan sampel menggunakan teknik class random sampling. Menurut Arikunto (2002:111) class random sampling pengambilan sampelnya, "mencampur" subjek-subjek dalam populasi sehingga semua subjek dianggap sama. Sampel dalam penelitian ini terdiri dari dua kelas yaitu kelas XI TITL2 Model Project Based Learning dengan jumlah siswa 32, sedangkan kelas XI TITL1 pembelajaran Konvensional dengan jumlah siswa 32.

Desain penelitian ini menggunakan metode penelitian quasi eksperiment, yaitu penelitian yang bertujuan untuk mengetahui ada tidaknya pengaruh atau akibat dari sesuatu yang ditimbulkan pada subjek yaitu siswa. Desain penelitian ini objek yang diteliti akan dites pada tes akhir yaitu posttest (hasil belajar) yang telah diberikan perlakuan dengan menggunakan model pembelajaran yang berbeda.

Tabel 1. Desain Penelitian Post-Test Only Control Group Design

\begin{tabular}{|l|c|c|}
\hline Kelompok & Perlakuan & Post Test \\
\hline Eksperimen & $\mathrm{X}_{1}$ & $\mathrm{~T}_{2}$ \\
\hline Kontrol & $\mathrm{X}_{2}$ & $\mathrm{~T}_{2}$ \\
\hline
\end{tabular}

Instrument Penelitian dan Teknik Pengumpulan Data:

1) Tes hasil belajar

2) Uji Validitas

3) Daya Pembeda Soal

4) Uji Taraf Kesukaran Soal

5) Uji Reliabilitas

Penelitian yang dilakukan pada populasi jelas akan menggunakan statistik deskriptif dalam analisisnya Sugiyono, (2010 : 208). Hal itu dikarenakan peneliti menggunakan seluruh siswa kelas XI Program Kompetensi Teknik Instalasi Tenaga Listrik sebagai subjek penelitiannya. Jadi, penelitian ini dilakukan pada populasi tanpa diambil sampelnya. Dalam penelitian ini, rumus statistik yang digunakan untuk menganalisis data adalah rumus mean atau rata - rata. Mean didapat dengan menjumlahkan data seluruh individu pada kelompok kemudian dibagi dengan jumlah individu yang ada pada kelompok tersebut (Sugiyono, 2012: 49).

Untuk menganalisis data yang akan mencari pengaruh, sebelumnya perlu diketahui apakah data tersebut memenuhi persyaratan analisis antara lain penelitian mempunyai distribusi yang normal dan homogen. Untuk itu dilakukan uji normalitas dan homogenitas. Untuk uji normalitas digunakan uji Liliefors dan uji homogenitas digunakan uji Barlett, teknik analisis ini cocok digunakan untuk menguji data yang terdiri dari beberapa kelompok. 


\section{HASIL DAN PEMBAHASAN \\ Hasil Penelitian \\ Deskripsi Hasil Belajar Siswa}

Kedua sampel dalam penelitian diberikan perlakuan yang berbeda yaitu dengan menggunakan model pembelajaran project based learning pada kelas eksperimen TITL 2 dan menggunakan model pembelajaran konvensional pada kelas control TITL1. Pada akhir proses pembelajaran diberikan test akhir (posttest) untuk mengetahui hasil belajar siswa dari kedua kelas tersebut.

Tabel 2. Distribusi Frekuensi Hasil Belajar Siswa Kelas Eksperimen.

\begin{tabular}{|l|l|l|l|}
\hline Kelas & Interval & $\mathrm{F}_{\text {absolut }}$ & $\begin{array}{l}\mathrm{F}_{\text {relatif }} \\
(\%)\end{array}$ \\
\hline 1 & $63-68$ & 4 & $13 \%$ \\
\hline 2 & $69-74$ & 8 & $25 \%$ \\
\hline 3 & $75-80$ & 12 & $38 \%$ \\
\hline 4 & $81-86$ & 4 & $13 \%$ \\
\hline 5 & $87-92$ & 4 & $13 \%$ \\
\hline Jumlah & 32 & $100 \%$ \\
\hline
\end{tabular}

Distribusi frekuensi hasil belajar siswa kelas eksperimen dapat dilihat bahwa jumlah siswa memperoleh nilai dibawah nilai raata-rata kelas 1 dan 2 adalah $38 \%$. Siswa yang memperoleh nilai rata-rata 77, 33 pada kelas 3 sebanyak $38 \%$. Sedangkan siswa yang memperoleh nilai diatas rata-rata pada kelas 4 dan 5 sebanyak $26 \%$.

Tabel 3. Distribusi Frekuensi Hasil Belajar Siswa Kelas Kontrol

\begin{tabular}{|l|l|l|l|}
\hline Kelas & Interval & $\mathbf{F}_{\text {absolut }}$ & $\begin{array}{l}\mathbf{F}_{\text {relatif }} \\
(\mathbf{\%})\end{array}$ \\
\hline 1 & $60-64,5$ & 8 & $25 \%$ \\
\hline 2 & $65,5-70$ & 11 & $34,37 \%$ \\
\hline 3 & $71-75,5$ & 3 & $9,37 \%$ \\
\hline 4 & $76,5-81$ & 7 & $21,87 \%$ \\
\hline 5 & $82-86,5$ & 2 & $6,25 \%$ \\
\hline 6 & $87,5-92$ & 1 & $3,12 \%$ \\
\hline Jumlah & $\mathbf{3 2}$ & $\mathbf{1 0 0}$ \\
\hline
\end{tabular}

Distribusi frekuensi hasil belajar siswa kelas kontrol dapat dilihat bahwa jumlah siswa yang dibawah nilai rata-rata sebesar 59,37\%. Sedangkan hasil belajar siswa yang memperoleh nilai ratarata adalah sebesar $9,37 \%$. Untuk siswa yang memperoleh hasil belajar diatas nilai rata-rata sebesar $31,24 \%$.

\section{Tingkat Kecenderungan}

Tabel 4.Tingkat kecenderungan kelas eksperimen

\begin{tabular}{|c|c|c|c|}
\hline Nilai & F. Observasi & F. Relatif $(\%)$ & Kategori \\
\hline$>84,00$ & 4 & $12,5 \%$ & Tinggi \\
\hline $77 \mathrm{~s} / \mathrm{d} 84,00$ & 16 & $50 \%$ & Cukup \\
\hline $70 \mathrm{~s} / \mathrm{d} 77$ & 8 & $25 \%$ & Kurang \\
\hline$<70$ & 4 & $12,5 \%$ & Rendah \\
\hline Jumlah & 32 & $100 \%$ & \\
\hline
\end{tabular}


Tabel 5. Tingkat Kecenderungan Kelas Kontrol

\begin{tabular}{|c|c|c|c|}
\hline Nilai & F. Observasi & F. Relatif (\%) & Kategori \\
\hline$>80,62$ & 3 & $9,3 \%$ & Tinggi \\
\hline $73,75 \mathrm{~s} / \mathrm{d} 80,62$ & 7 & $21,8 \%$ & Cukup \\
\hline $66,88 \mathrm{~s} / \mathrm{d} \mathbf{7 3 , 7 5}$ & 10 & $31,2 \%$ & Kurang \\
\hline$\langle 66,88$ & 12 & $37,5 \%$ & Rendah \\
\hline Jumlah & 32 & $100 \%$ & \multicolumn{1}{|c}{} \\
\cline { 1 - 3 } & & &
\end{tabular}

\section{Pengujian Persyaratan Analisis}

1) Uji Normalitas

Tabel 6. Hasil Uji Normalitas

\begin{tabular}{|l|l|l|l|l|}
\hline No. & Kelas & $\mathbf{L}_{\text {hitung }}\left(\mathbf{L}_{\mathbf{0}}\right)$ & $\mathbf{L}_{\text {tabel }}$ & Status \\
\hline 1. & Eksperimen & 0,10925 & 0,1566 & Normal \\
\hline 2. & Kontrol & 0,15131 & 0,1566 & Normal \\
\hline
\end{tabular}

Dari tabel di atas diperoleh $\mathrm{L}_{\text {hitung }}<\mathrm{L}_{\text {tabel }}$ yaitu $0,10925<0,1566$ dan $0,15131<0,1566$ sehingga disimpulkan bahwa data kedua kelas tersebut berdistribusi normal.

2) Uji Homogenitas

Untuk menguji homogenitas menggunakan uji F. Uji F dapat dicari dengan membandingkan varians terbesar dengan varians terkecil. Dari hasil perhitungan uji $\mathrm{F}$ terdapat pada lampiran 15 , diperoleh $\mathrm{F}_{\text {hitung }}<\mathrm{F}_{\text {tabel }}$ yaitu 1,25 $<1,81$ dengan demikian dapat disimpulkan bahwa data homogen.

3) Uji Hipotesis

Dari hasil perhitungan terdapat pada lampiran 16 diperoleh $t_{\text {hitung }}=3,261$ dikonsultasikan dengan $\left.\mathrm{t}_{\text {tabel }} \mathrm{dk}=\left(\mathrm{n}_{1}+\mathrm{n}_{2}-2\right)=32+32-2\right)=62$ pada taraf $\alpha=0,05$, maka dk 62 terdapat pada tabel distribusi $t$ adalah 1,670. Sehingga $t_{\text {hitung }}>t_{\text {tabel }}$ yaitu 3,261 $>1,670$, sehingga dapat disimpulkan bahwa hipotesis alternative (Ha) dalam penelitian ini diterima sekaligus menolak hipotesis nihil (Ho) dengan kata lain hasil belajar siswa kelas XI Teknik Instalasi Tenaga Listrik pada kompetensi dasar instalasi dan pengukuran sistem pembumian dengan menggunakan model belajar Project Based Learning (PJBL).

\section{Pembahasan}

Berdasarkan analisis data hasil belajar dalam penelitian setelah diberikan perlakuan terhadap kelas eksperimen dengan model pembelajaran project based learning diperoleh hasil belajar siswa dengan nilai rata-rata 77,33 dan untuk kelas kontrol dengan menggunakan model pembelajaran konvensional diperoleh rata-rata 71,16. Dari hasil nilai rata-rata dari kedua kelas telah terjawab bahwa kelas eksperimen $\left(\mu_{1}\right)$ lebih tinggi dari pada kelas kontrol $\left(\mu_{2}\right)$. Pada lampiran 13 dapat dilihat bahwa nilai hasil belajar kelas eksperimen pada umumnya tergolong dalam kategori cukup (50\%), sedangkan nilai dari hasil belajar kelas kontrol tergolong dengan kategori rendah $(37,5 \%)$.

Hasil pengujian hipotesis diperoleh harga $t_{\text {hitung }}>t_{\text {tabel }}$ yaitu 3,261 $>1,670$ dengan taraf signifikan $5 \%(\alpha=0,05)$ sehingga Ha diterima yang berarti hasil belajar siswa kelas XI Teknik Instalasi Tenaga Listrik pada kompetensi dasar memahami instalasi dan pengukuran sistem pembumian dengan menggunakan model pembelajaran project based learning lebih tinggi dari hasil belajar dengan menggunakan model pembelajaran konvensional.

\section{SIMPULAN}

Hasil belajar siswa kelas XI Teknik Instalasi Tenaga listrik SMK N 1 Percut Sei Tuan dengan menggunakan model pembelajaran project based learning dapat dikategorikan cukup dengan nilai rata-rata 77,33 pada kelas eksperimen kompetensi memahami instalasi dan pengukuran sistem pembumian. Hasil belajr siswa kelas XI Teknik Instalasi Tenaga Listrik SMK N 1 Percut Sei Tuan dengan menggunakan model pembelajaran konvensional dapat 
dikategorikan kurang dengan nilai rata-rata 71.16 pada kontrol kompetensi memahami instalasi dan pengukuran sistem pembumian.

Berdasarkan hasil perhitungan uji $t$ diperoleh harga $t_{\text {hitung }}>t_{\text {tabel }}$ yaitu 3,261 $>1,670$ dengan taraf signifikan $5 \%(\alpha=0,05)$ sehingga Ha diterima. Dengan kata lain hasil belajar siswa kelas XI Teknik Instalasi Tenaga Listrik pada kompetensi memahami instalasi dan pengukuran sistem pembumian dengan menggunakan model pembelajaran project based learning lebih tinggi dari hasil belajar siswa dengan menggunakan model pembelajaran konvensional. Hal ini dilihat dari hasil belajar siswa memahami instalasi dan pengukuran sistem pembumian, dengan nilai rata-rata 77,33.

\section{DAFTAR PUSTAKA}

Arikunto. 2014. Prosedur Penelitian Suatu Pendekatan Praktik. Jakarta: Rineka Cipat

Ngalimun. 2014. Model Dan Model Pembelajaran. Yogyakarta: Aswaja Pressindo.

Fathurrohman, Muhammad. 2015. Model-Model Pembelajaran Inovatif. Jogjakarta: Ar-Ruzz Media Istarani. 2017. 58 Model Pembelajaran Inovatif. Medan: Media Persada.

Rohman, I., \& Yundra E. 2016. Pengembangan Perangkat Pembelajaran Project Based Learning Pada Standar Kompetensi Mengoperasikan Power Supply Elektronika Computer Industry Di SMK Negeri 2 Bojonegoro. Jurnal Pendidikan Teknik Elektro, 05 (1):259-263.

Parmani, A,D., Sumiati., \& Meliasari. 2019. Modifikasi Model Pembelajaran Project Based Learning Dengan Model Pembelajaran Tugas Dan Paksa. Seminar Nasional Pendidikan KALUNI, 2 : 322- 333.

Fatkhurrokhman,M., \& Dkk. 2017. Pengembangan Perangkat Pembelajaran Teknik Digital Berbasis Project Based Learning Di Jurusan Pendidikan Teknik Elektro. Jurnal Pendidikan Vokasi, 7 (1) : 101-109.

Wahyu, P. 2014. Pengaruh Pembelajaran Project Based Learning Terhadap Hasil Belajar Siswa Pada Standar Kompetensi Mengoperasikan Pengendali PLC Di SMK N 1 Madiun. Jurnal Pendidikan Teknik Elektro, 3 (3) : 455-461.

Abdillah, M. 2016. Sistem Distribusi Tenaga Listrik. Pontianak : Yayasan Kemajuan Teknik.

Aslimeri, dkk. 2008. Teknik Transmisi Tenaga Listrik Jilid 2. Jakarta : Direktorat Pembinaan Sekolah Menengah Kejuruan.

Sarimun, W. 2011. Buku Saku Pelayanan Teknik. Depok: Garamond.

Syam, N, A. 2016. Pengaruh Model Pembelajaran Berbasis Proyek (Project Based Learning)Terhadap Hasil Belajar Biologi Siswa Di Kelas VIII MTS Madani Alauddin Paopao, Skripsi, Fakultas Tarbiyah dan Keguruan, UIN Alauddin, Makassar.

Prasetyo, A. 2017. Penerapan Model Pembelajaran Project Based Learning Berbasis Media Peraga Untuk Meningkatkan Hasil Belajar Siswa Pada Mata Pelajaran Ukur Tanah Kelas X Di SMK N 3 Semarang, Skripsi, Fakultas Teknik, Universitas Negeri Semarang, Semarang.

Kurniasari, D,R. 2017. Penerapan Model Pembelajaran Project Based Learning Untuk Meningkatkan Hasil Belajar Fisika Dan Keterampilan Proses Peserta Didik Kelas X SMA N 1 Banguntapan, Skripsi, Fakultas Matematika dan ILmu Pentahuan Alam, Universitas Negeri Yogyakarta, Yogyakarta.

Sudjana, N. 2010. Penilaian Hasil Proses Belajar Mengajar. Bandung: PT. Remaja Rosda Karya. Sitompul, H. 2019. Pedoman Penulisan Skripsi/Tugas Akhir. Medan: 